\title{
The Influence of Vision, Mission, and Values Statement on Performance and the Organization of Economic Education Study Program Faculty of Teacher Training and Education Science
}

\author{
Witarsa \\ Tanjungpura University \\ witnessedu@yahoo.com
}

\begin{abstract}
Vision and mission statement of economic education courses have been good, but in result practice is not ideal, especially in the field of research and community service. To realize the vision and mission statement of values needed as the main priorities in moving and improved organizational performance. The purpose of research is to describe the effect of vision, mission statement and values to organizational performance in economic education program Faculty of Teacher Training and Education Tanjungpura University. The method used is multiple linear regressions. The results showed that there is significant influence either partially or simultaneously statement of vision, mission, and values to organizational performance. Vision statement is a variable most dominant influence on the perform of economic education courses.
\end{abstract}

Keyword-vision, mission and values statement, organizational performance.

\section{INTRODUCTION}

The vision and mission are a standard and important element of the strategy of public and non-public organizations. The most well-established public organizations to develop the organization's mission statement and vision statement, which serves as a basic guide in the formation of desired organizational objectives with a target achievement of short-term, medium and long term. Achieving the vision and mission of economic education courses required statement of values as the main priorities in moving purposes. Value defines the basic philosophy, principles and ideals of the organization. Value plays regulate the behavior of duties and responsibilities of faculty members or lecturer for working to achieve its vision and mission. The purpose is to personalize the mission statement of values for the achievement of the strategy study programs organasasi short-term performance by realizing economies accredited study program in 2015 obtained accreditation B value of BAN-PT with a target value of hope in 2017 obtained accreditation A.

The outline of the research issues: (1) whether there is any direct influence statements of vision, mission, and values towards the performance of the Organization in the Economic Education FKIP Tanjungpura University (2) whether there was influence of simultaneous and partial statement of vision, mission, and values towards organizational performance (3) what factors determine the improvement of organizational performance in Economic Education (4) how to model the performance of the Organization in the economic education courses.

\section{LITERATURE REVIEW}

Vision is generally seen as a picture of the future. It is a picture of excellence, something that the person, team or organization wants to create in its best possible future. [1] Vision guides and perpetuates corporate existence. Vision is viewed as a mental picture of a compelling future situation. It originates from creative imagination, the act or power of perceiving imaginative mental images, sort of foresightedness. [2] Vision presents an organization's desired future state projection and the mission explains the purpose and the reason of the organization's present existence. Vision and mission are connected and intertwined. [3] Bubble et al (Čuić Tanković A, 2013) Visionary future primarily describes the state of the organization 10 and 30 years from now. It requires predictions that overcome current conditions and resources. It has to be challenging as well as stimulating for the organization itself because all future activity is based on it. [4] [5]

Characters vision on University of Hawai'i as follows:

- Be inspirational. The vision statement is supposed to challenge, enthuse and inspire. Use powerful words and vivid phrases to articulate the kind of institution you are trying to become. This is your chance to lift your institution's gaze above the grind of day-to-day gripes and problems and to focus attention on 'the bigger picture' and the potential rewards that await.

- Be ambitious. If you set your sights on being 'within the top 10' the chances are that the best you will come is 10 th. If your real aim is to hit the top 5, why not say so and go for broke? What argots you set and how high you aim will, in themselves, also say something about you as an organization. Ambitious, perhaps even audacious targets will help create the impression of an organization that is going places, that aims high and demands high standards from its 
staff and students in a way that comfortable, 'middleof-the-road' benchmarks will not

- Be realistic. This may sound odd following on immediately from a call to 'Be ambitious', perhaps even contradictory, but it is an important part of the balancing act that is required. For just as the purpose of the vision is to inspire and enthuse, it is equally important that this ambition is tempered by an underlying sense of realism. People need to believe that what is envisaged is actually achievable; otherwise there is no reason for them to believe or buy in to it. It is perfectly possible to be both ambitious and realistic and it is through successfully marrying these two forces that the best vision statements will be formed. Stating that you will become 'ranked in the top 3 in the student satisfaction league table within 5 years' may be both ambitious and realistic if you currently sit at number 7 , but sound far less convincing if you currently reside at number 57

- Be creative. Albert Einstein once said that 'imagination is more important than knowledge.'1 Of course, there is nothing wrong with saying that you will 'deliver world-class learning and teaching standards but it is probably a safe bet that at least a dozen other institutions will be saying the same thing. Just as a commercial company may need to think creatively in order to identify gaps in the market, so too you may need to think imaginatively about what your vision is and how you describe it to help stand out from the crowd

- Be descriptive. Unlike with your mission statement, there is no pressure to pare your vision down to the bone. Of course you want to be concise (indeed many of the best examples of memorable visions to tend to be so), but there is no need to enforce an arbitrary limit on its length. Take as much space as you need to get your vision across

- Be clear. As with your mission statement it pays to avoid jargon, keep sentences short and to the point and use precise, uncluttered language. Otherwise you risk diluting or losing your message amongst the background 'noise'

- Be consistent. Though bearing in mind their different purposes, there should still be an element of continuity between your mission and vision statements, or at least some careful thought and discussion given as to why this is not the case. At the same time, the vision need not be constrained by the current remit of the mission. Perhaps the institution is keen to explore new areas in the future: to become the region's conference venue of choice, for example, in which case this would need to be reflected in the mission statement in due course

Mission describes the organization's identity, product, market and the particular methodology or technology of emphasis. The mission statement incorporates specifics about the organization that make it unique and describes "the organization's achievement hopes, such as the size of the organization, the scope of endeavor and the number and diversity of the organization's businesses, markets and customers" in Čuić Tanković.

Mission usually reflects the values and priorities of strategic decisions and outlines the vision and future organization's direction. The mission statement goal is ensuring the planned behavior by following the mission guidelines as well as explaining the purpose of existence and the business as a whole to intern and extern stakeholders. According to mission statement should be market oriented, real, clear, enforceable, motivating, specific, flexible enough and environment adaptable. From the customer's point of view, the mission statement ensures the frame of his expectations. For the employee, it is the impulse to understand that the decisions the management makes are good.

The results of the study at the college as a character on a mission of the University of Hawai'i as follows:

- Make it as succinct as possible. A mission statement should be as short and snappy as possible preferably brief enough to be printed on the back of a business card. The detail which underpins it should be mapped out elsewhere.

- Make it memorable. Obviously partially linked to the above, but try to make it something that people will be able to remember the key elements of, even if not the exact wording

- Make it unique to you. It's easy to fall into the 'motherhood and apple pie' trap with generic statements that could equally apply to any institution. Focus on what it is that you strive to do differently: how you achieve excellence, why you value your staff or what it is about the quality of the student experience that sets you apart from the rest.

- Make it realistic. Remember, your mission statement is supposed to be a summary of why you exist and what you do. It is a description of the present, not a vision for the future. If it bears little or no resemblance to the organization that your staff know it will achieve little

- Make sure it's current. Though it is not something which should be changed regularly, neither should it be set in stone. Your institution's priorities and focus may change significantly over time - perhaps in response to a change of direction set by a new, or major changes in state/federal policy. On such occasions the question should at least be asked: 'does our current mission statement still stand?'

Mission and vision statements have been overwhelmingly accepted as an indispensable part of the strategic management process for organizations of all types; be it public sector, not-for-profit, private, for profit, a multinational or a small and medium scale enterprise. It is widely believed that mission and vision statements impact 
on strategy and most aspects of organizational performance. [7]

The length and content of mission and vision statements may vary; some broad others narrow. Fundamentally vision statements include and capture a myriad of stakeholder values and expectations; more importantly how the organization creates value for its stakeholders. [8] A typical mission statement identifies key stakeholders and states the organization's commitment to meet these stakeholders ${ }^{\text {ee }}$ needs. He went on to suggest the concept of ,measurable ${ }^{\text {ee }}$ as key to the practical application of the mission: These „measurable ee are hybrid of goals and objectives. [9]

To succeed in the realization of the vision and mission statements, the required statement of values, as expressed by William and Paul (2001), a values statement clarifies how the organization will conduct its activities to achieve the organization's mission and vision. It is a statement about how the organization will Value patients, staff, suppliers and the community. Values statements, reflecting Common morality, frequently emphasize respect, integrity, trust, caring and excellence. [10]

Statement of value as guidelines the attitude of ethics, responsibility, and a commitment to carry out the vision and mission of the organization. The description of the vision statement and the mission should be able to provide confidence in the form of a statement of value to members so that all members are aware that the vision and mission strategic objectives is the weapon of the future organization.

Organizational performance is a reflection of the transformation of inputs into outputs in order to achieve certain results. The performance of the Organization informed about the relationship between the minimal cost and effective (economic), between the output efficiency.

Organizational performance is getting more and more important, especially in a market with greater competition and dynamic. Organizational performance is measured through different indicators. It guarantees the continuity of the organization to be competitive in a global marketplace. Normally, the implementation of performance indicators achieved through human resources. Human resources are the key for keeping the organization in the market so competitive. [11]

Performance successful and sustainable organization will strive to continuously or never stop developing a vision statement, mission, and values. While the staff in the organization had to work extra to support the achievement of the organization's performance.

The ultimate success of a change strategy depends greatly on how the change is introduced and implemented, rather than on the merit of the strategy itself. Successful development and utilization of key performance indicators (KPIs) in the workplace is determined by the presence or absence of four foundation stones. [12]

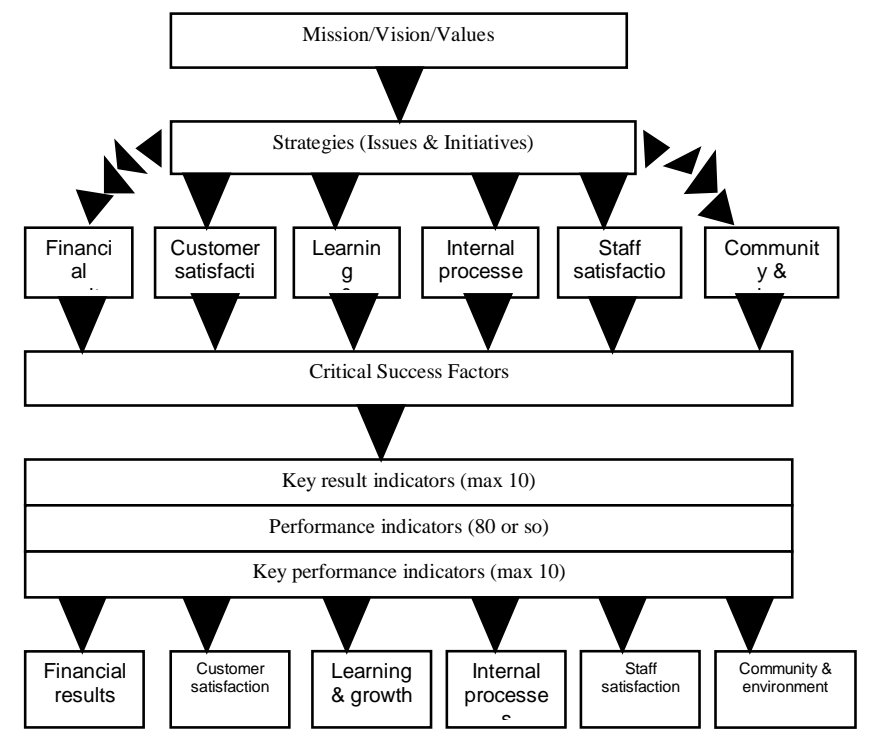

Fig. 1. Journey from a Mission and Vision to Performance Measures that Work in David, Parmenter

From the picture, it can be seen that the statement of vision, mission, and values are key variables that affect the achievement of organizational performance indicators. In a study of performance indicators adopted the figure 2.1, which is then adjusted to the conditions of organizational performance in the area of research.

Based on the description, then put forth a model framework for theoretical from the direction of research is as follows:

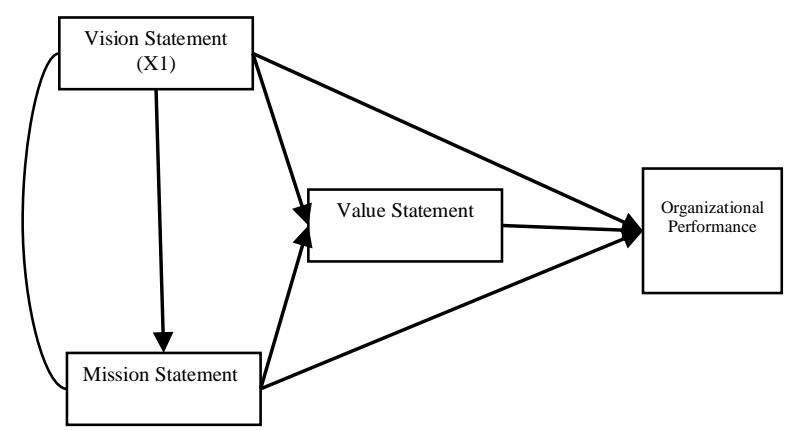

Fig. 2. Theoretical Framework Hypothesis Line Model

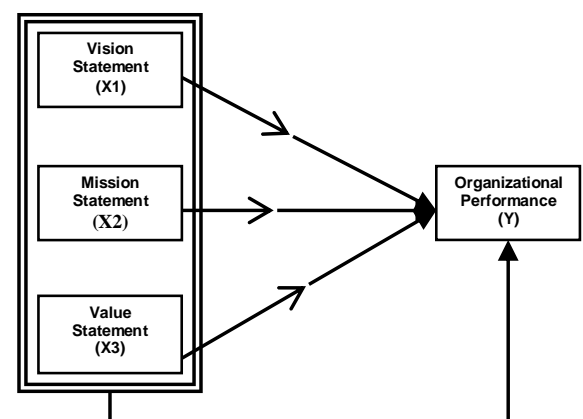

Fig. 3. Theoretical Framework Hypothesis Multiple Corelation Model 
Based on the description of the conceptual and theoretical framework model hypothesis, further research hypothesis put forward as follows: (1) A statement of vision, mission, and values the positive direct effect on organizational performance in the Economic Education Studies Program FKIP Untan. (2) A statement of vision, mission, and values influence simultaneously and partially on the performance of the organization in Economic Education Studies Program FKIP Tanjungpura University.

\section{RESEARCH METHOD}

This study used a descriptive approach using a survey, which is an approach that aims to measure the dependent and independent variables to predict the way through the sample of the population are alumni of Economic Education Studies Program FKIP Untan who have worked and continue their studies domiciled in Pontianak. From the results of hunting primary data, the number of respondents who live in Pontianak sample of 40 people.

The data collection technique using the data collected through a questionnaire listing. Then the questionnaire as a research instrument was tested with validity and reliability. Based on the results of testing of research instruments against 25 people thought to be aware of the variables studied, showed that the validity of each variable> 0.30 . While the results of the reliability Corrected Item-Total Correlation and Cronbach's Alpha if Item Deleted> 30 and results reliabiltas Cronbach's Alpha> 60 .

Research data will be analyzed by multiple linear regression techniques with the formula: $Y=\beta_{0}+\beta_{1} X_{1}+$

$\beta_{2} X_{2}+\beta_{3} X_{3}+\epsilon$

Description :

$\mathrm{Y}=$ Organizational Performance

$\beta_{0}=$ Intersep

$\mathrm{X}_{1}=$ Vision Statement

$\mathrm{X}_{2}=$ Mission Statement

$\mathrm{X}_{3}=$ Value Statement

\section{$\epsilon=$ error terms}

In a multiple regression model to estimate, performed classical assumption test requirement in the form of calculation multikolinieritas, normality and linearity of data, and heterokedastisitas. From the calculation results of multiple regression that all requirements are met.

$$
\text { IV. RESULT }
$$

Analysis of data obtained from the results of the research hypothesis line as follows:

\section{Data Analyisis Table}

\begin{tabular}{|lll|c|l|}
$\begin{array}{l}\text { Hypothesis } \\
\text { Line }\end{array}$ & Effect of Variabel & Direct & $T_{\text {count }}$ ttabel1,98 & $\begin{array}{l}\text { Sig.t } \\
<0,05\end{array}$ \\
\hline Py1 & X1 $\rightarrow$ Y & 0,433 & 3,232 & 0,003 \\
Py2 & X2 $\rightarrow$ Y & 0,268 & 2,451 & 0,019 \\
\hline Py3 & X3 $\rightarrow$ Y & 0,305 & 2,780 & 0,009 \\
\hline P31 & X1 $\rightarrow$ X3 & 0,699 & 6,024 & 0.000 \\
\hline P32 & X2 $\rightarrow$ X3 & 0,479 & 3,361 & 0.002 \\
\hline P21 & X1 $\rightarrow$ X2 & 0,695 & 5,965 & 0.000 \\
\hline
\end{tabular}

Based on Table 1, presented the results of the overall hypothesis lines as follows:

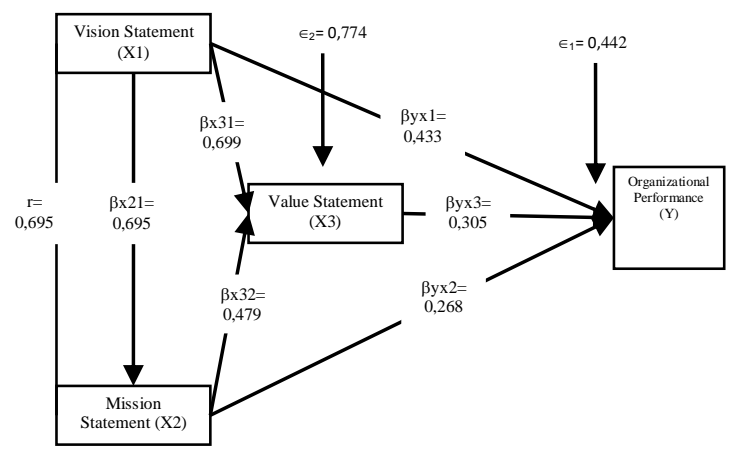

Fig. 4. Empirical Causal Model

While the results of multiple correlation hypothesis can be seen in the following figure:

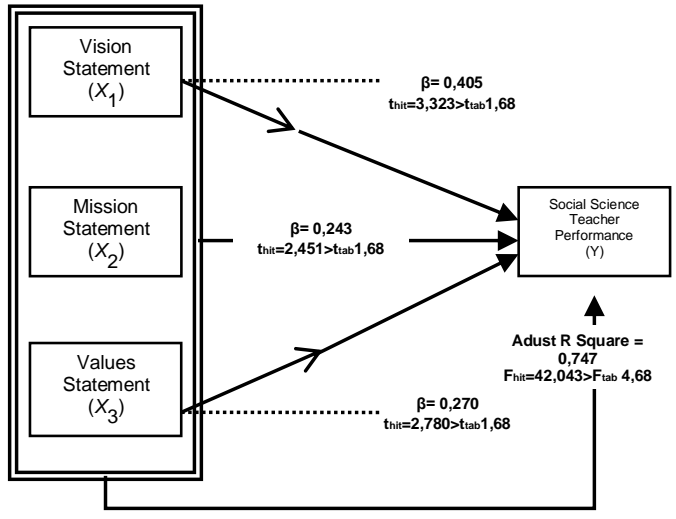

Fig. 5. Influence of Partial Positive and simultaneous $\mathrm{x} 1, \mathrm{x}$ 2, X 3 Against Y

\section{DISCUSSION}

The results of the empirical finding that the mission statement of positive direct effect on performance of the organization. This empirical finding was reinforced by Eric Van den Steen (2005) which States "In line with the original management literature on the topic, I then define "vision" as a strong belief by the manager about the future and about the right course of action for the firm. To evaluate the profitability of hiring a manager with such vision, I take the perspective of an outsider, such as the board, with a "reference"' belief and show that it is often optimal for such outsider to hire a manager whose beliefs are strictly stronger than his own. Such vision will be most effective with high uncertainty and low contractibility. This suggests that vision will be more important for, for example, high-tech industries and start-ups than for established firms in mature industries. [13]

Noting the opinion that the success highly depends on the vision to be achieved by the organization for Economic Education study program in the long term between 5-10 years. This achievement uniformly perceived by members of the organization and the people who care about the 
progress of the Economic Education study program on an ongoing basis. The vision statement is important and should be on every organization that wants to go forward. This vision which then drives a wide range of targets to be achieved. Vision with a targeted payload will help lead the organization goals, objectives, and indicators of success to be successful achieved. Vision implemented reflect the performance of an effective organization.

Successful organizational performance should be viewed as the performance of the organization's future performance. Organizational performance cannot be achieved by operating in a vacuum, but there must be laying models aim to articulate the organization's activities, how it is done, how do organizations create and create opportunities, do what characterizes excellence, and is able to satisfy the member, customer or user.

Vision statement are perceived the respondent has fulfilled expectations means capable of satisfying a member, customer or user. Of the research data the better vision, then the better the performance of the Organization in economic education courses. A good organizational performance must be supported by measures to work with a specific standard operating procedures that are clear and measurable.

Empirically, this research was supported by the William (2012), which explains that knowledge and perceptions about mission and vision statements and has shown that mission and vision statements are still relevant strategic management tools that can impact employee behavior and attitudes in consistence with other empirical studies. Attempts were particularly directed towards probing and highlighting issues relating to awareness of mission and vision statements, leading to ownership and subsequently impact.

To succeed in the realization of the vision and mission statements, the required statement of values, as expressed by William and Paul (2001), a values statement clarifies how the organization will conduct its activities to achieve the organization's mission and vision. It is a statement about how the organization will Value patients, staff, suppliers and the community. Values statements, reflecting Common morality, frequently emphasize respect, integrity, trust, caring and excellence.

Statement of value as guidelines the attitude of ethics, responsibility, and a commitment to carry out the vision and mission of the organization. The description of the vision statement and the mission should be able to provide confidence in the form of a statement of value to members so that all members are aware that the vision and mission of strategic weapons is achieving the objectives of the Organization of the future.

Vision, Mission, and Values statement, its implementation can be seen on the purpose of the Implementation of Economic Education Studies Program is to produce graduates who master a number of competencies, namely:

- Being able to know the basic knowledge in the field of economics education both national and international level and able to develop and apply it in a professional manner.

- Able to carry out educational and economic studies,

- Able to respond to a variety of educational paradigm changes, especially on Economic Education curriculum development

- Able to implement the competence of educational profession

- Being able to conduct familiarization institutional economics to students based economic rationality and morality

- Able to respond and adapt to the environment and culture at local, national and global culture

- Able to conduct surveys, studies, or research and economic education

- Being able to calculate the economic feasibility of micro small and medium enterprises

- Capable and skillful in charge of entrepreneurship and widiayaswara industry

System of governance in the Economic Education study program run effectively through mutually agreed mechanisms, as well as be able to maintain and accommodate all the elements, functions, and roles in the study program. Governance is supported by organizational culture which is reflected by the existing and the establishment of rules, procedures of electing the leadership, ethics professors, student's ethics, ethics education personnel, system of rewards and sanctions as well as the guidelines and procedures (administration, libraries, laboratories, and studios). Governance system (inputs, processes, outputs and outcomes as well as the external environment which ensures the implementation of good governance) should be formulated, disseminated, implemented, monitored and evaluated with clear rules and procedures.

Interests and Animo High School Graduates who want to continue to Study Economic Education Program to date are quite a lot. In the year 2013/2014 the national interest of high school as much as 1274 participants, in the year $2014 / 2015$ the national interest of high school as much as 1415 participants, lecturers remained Economics Education courses comprise a total of 18 lecturers. Lecturer qualified doctoral education as many as 14 people and as many as four Masters lecturers. Lecturers who have positions Associate Professor and Professor of as many as 15 people and Lecturers who have teaching certificate by 17 lecturers. Activities tenured whose expertise in accordance with the study program is expressed in the average credits per semester in the last academic year, filled with calculations in accordance Director General of Higher Education Decree no. 481983 (12 credits equivalent to 36 hours per week).

Prepared curriculum refers to the vision, mission, goals, and objectives of economic education studies program. The curriculum is owned by the Economic Education Studies Program was designed based on their relevance to the objectives, scope and depth of the material, the organization that encourages the formation of hard skills and personality 
and behavioral skills (soft skills) that can be applied in various situations and conditions. Management and accountability are always reported at the end of the budget (closing) FKIP and then reported to the University Tanjungpura. In Fiscal years 2014/2015 Tri Dharma Higher education funding: Rp 3.27312 billion with an allocation of $58.07 \%$ Education, Research 28, 14\% and CRP of $2.99 \%$, 4.37\% Investment Facility, the Investment Facility $4.37 \%$, and $5.34 \%$ human Resources Investment.

Economic education courses adapted from the University information system includes: 1) management information systems Academic Administration (Sistem informasi Manajemen Administrasi Akademik / SIMAK), 2) the financial information system (Sistem Informasi Keuangan / SIAKU), 3) Staffing information system (Sistem Informasi Kepegawaian / SIMPEG), and 4) State-owned Goods information system (Sistem Informasi Barang Milik Negara / BMN. Research conducted by the lecturers during the period of the last three years a total of 27 studies (21 studies DIPA funds sourced from the Faculty, 1 research sourced from BOPTN funds, 4 research comes from the Higher Education Fund, and the first research in collaboration with the Government of Bengkayang).

Mutu, efektifitas dan relevansi Program Studi Pendidikan Ekonomi dapat diketahui melalui kegiatan evaluasi oleh mahasiswa dan staf tenaga pengajar, serta evaluasi terhadap materi kuliah dan proses pembelajaran secara umum. Program Studi Pendidikan Ekonomi memiliki sarana dan prasarana sistem informasi yang baik meliputi perpustakaan dengan teknologi informasi fasilitas internet dan intranet telah tersedia dengan tenaga pendukung yang cukup.

The strategy was developed and has been done the last three years: (1) Repair conducive academic atmosphere; (2) Upgrading the qualifications of faculty and administration; (3) Increased implementation of SCL or Student Learning Centre ; (4) Utilization of technology and information management systems and internal organization; (5) Improving efficiency through utilization of facilities and infrastructure along with other courses in the neighborhood FKIP; and (6) Striving continuously sustainable program of study by utilizing available resources through cooperation and partnerships.

From the study of theory, empirical studies, and these explanations, that the vision and mission statements will be better if accompanied by a statement of values. A statement on Economic Education Studies Program provides core values, namely the value of organizational climate that guarantees and develop: (1) freedom of inquiry and expression. (2) Democracy. (3) the freedom to innovate, (4) compact. (5) eliminate discrimination, (6) Cultural organizations. Implementation of the core value above 5 requires institutional support, especially the faculty. Faculty support is encouraging to improve organizational performance by facilitating the realization of (1) accreditation process, achieving an A. (2) curriculum Academic Qualifications Framework: a profile of graduates, learning achievements, the depth and breadth of subjects, distribution of courses and curriculum structure , (3) a harmonious relationship of faculty and students, (4) Improving education and teaching, research and dedication to masyaraka, (5) lifelong learning. Universities Support namely: (1) realize the Financial Budget Plan, (2) reviewing the budget realization. (3) acceptance of students,. (4) the promotion of excellence courses, (5) accessibility of partnership opportunities with various parties, (6) Accessibility of quality assurance ,. (7) concern for the sustainability of economic education courses. From the findings and discussion of research, advanced models improved performance Economy education study program of the Faculty of teacher training and educational sciences of the University of Tanjungpura as follows:

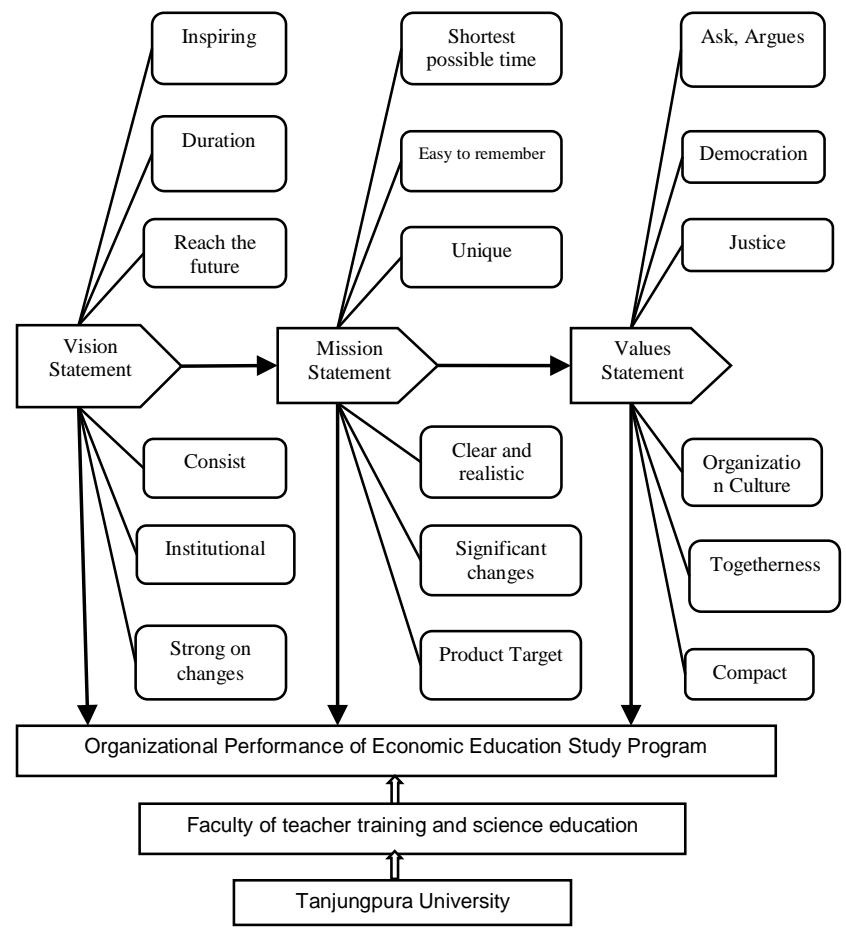

Fig. 6. Performance Model of Economic Education study program FKIP Untan

\section{CONCLUSION}

- There is a direct positive influence Vision Statement, Mission, and Values to Performance Studies Program Organization of Economic Education Studies Program. The direct effect of this shows that the seriousness implement Vision Mission, and Values Statement followed by an increase of Organizational Performance of Economic Education Studies Program.

- There is a partial effect on the Mission Statement to Organizational Performance of Economic Education Studies Program. This positive effect shows that the seriousness implements the Mission Statement, will 
result in an increase in Performance Studies Program Organization of Economic Education.

- There is a partial effect on the Statement of Value to Performance Organization of Economic Education Studies Program. This positive effect shows that the seriousness implement Value Statement, will result in an increase in Performance Organization of Economic Education Studies Program.

- There is a positive effect jointly Vision Statement, Mission Statement, and Statement of Value on the performance of the Organization of Economic Education Studies Program. This suggests that the effect of the simultaneous determination to implement the Vision Statement, Mission Statement, and Statement of Value, will result in improved performance of the Organization of Economic Education Studies Program.

- The vision statement is the dominant varibael will it affect organizational performance of Economics Education Study Program Faculty of teacher training and science education of Tanjungpura University, Pontinak.

- The deciding factor Increasing organizational performance of Economic Education Studies Program are: (1) Accreditation of courses reached an A. (2) Curriculum Academic Qualifications Framework: a profile of graduates, learning achievements, the depth and breadth of subjects, distribution of courses and curriculum structure. (3) The harmonious relationship of faculty and students. (4) Increased education and teaching, research and community service. (5) Philosophy of lifelong learning.

- The model of performance improvement in Economics Education Studies Program Faculty of teacher training and science education found by way of building up and developing the institutional model.

\section{REFERENCES}

[1] Z. Papulova (2014). The Significance of Vision and Mission Development for Enterprises in Slovak Republic. Journal of Economics, Business and Management, Vol. 2, No. 1, February 2014, p 13

[2] Joachim, "Interface between Corporate Vision, Mission and Production and Operations management, "GJMBR, vol. 10, no. 2 pp. 18-23, April 2010

[3] Čuić Tanković A, . 2013. Defining strategy using vision and mission statements of croatian organizations in times of crisis, Ekonomska istraživanja - Economic Research Special Issue 2013, p 332-442

[4] Alkhafaji, A., (2003) Strategic Management, Formulation, Implementation and Control in a Dy 7 namic Environment, The Haworth Press, New York

[5] Siân Millard (2013) Characteristics of Mission and Vision Statements . Uniersity of Hawai'i

[6] Lynch, R., (2006) Corporate strategy, Fourth edition, Prentice Hall, Engleska

[7] William Phanuel Kofi Darbi. Of Mission and Vision Statements and Their Potential Impact on Employee Behaviour and Attitudes: The Case of A Public But Profit-Oriented Tertiary Institution.
International Journal of Business and Social Science. Vol. 3 No. 14 [Special Issue - July 2012] 95-109

[8] Johnson, G., Scholes, K. and Whittington, R. (2008). Exploring Corporate Strategy: Text and Cases, (Eighth Edition), Prentice Hall, London.

[9] Mullane, J. V. (2002). "The mission statement is a strategic tool: when used properly", Management Decision, Vol. 40 No. 5, pp 448455.

[10] William A. Nelson., Paul B. Gardent. Healthcare executives need to lead the organization's culture in reviewing and implementing values statements. Harvard. Healthcare Executive MAR/APR2011, p, 56

[11] Luftim C (2014). The Impact of Strategic Human Resource Management on Organizational Performance Economia. Seria Management. Volume 17, Issue 2, 2014. P 372-383

[12] David, Parmenter (2007) Key Performance Indicators Developing, Implementing, and Using Winning KPIs. New Jersey John Wiley \& Sons, Inc, p, 19, 42

[13] Eric Van den Steen (2005) Organizational Beliefs and Managerial Vision,. he Journal of Law, Economics, \& Organization, Vol. 21, No. 1, p. 256-283 